\title{
DOI 10.26886/2414-634X.8(17)2017.2
}

UDC: $378.4: 631.3(043.3)$

PERSPECTIVE DIRECTIONS OF MODERNIZATION TO

VOCATIONAL TRAINING OF FUTURE MECHANICAL ENGINEERS

\section{AGRICULTURAL INDUSTRY}

\section{PhD in Pedagogical Sciences, O. Koshuk}

National University of Life and Environmental Sciences of Ukraine, Ukraine, Kiev

In article features of activity of modern engineers-agrarians, functions are analyzed (the analysis and technical forecasting; research; design, design; technological; regulations; operation and repair); which are proved on the basis of competence-based approach. The perspective directions of modernization of process of formation of professional competence of the specified experts are allocated: creative nature of training, formation of readiness of students for innovative engineering activity; purposeful formation of methodological culture of future engineers; realization of integrative methodological approach in pedagogical process, practice the focused nature of engineering training of students; integration of educational, research and production activity of future engineers-agrarians; coordination of agroengineering education with prospects of personnel requirements of agrarian production.

Keywords: engineering activity, functions, competence-based approach, engineer landowner, agrarian higher education institution, agricultural machiner.

кандидат педагогічних наук, Кошук О. Б. Перспективні напрями модернізація профресійної підготовки майбутніх інженерів-механіків Сільського господарства/ Національний університет біоресурсів $i$ природокористування України, Україна, Київ. 
У статті аналізуються особливості діяльності сучасних інженерів-аграрників, фуункії (аналізу і технічного прогнозування; дослідницька; конструкторська; проектування; технологічна; регулювання; експлуатації і ремонту); обгрунтовуються на засадах компетентнісного підходу. Виокремлено перспективні напрями модернізації процесу фрормування профресійної компетентності вказаних фрахівців: творчий характер навчання, фрормування готовності студентів до інноваційної інженерної діяльності; цілеспрямоване фрормування методологічної культури майбутніх інженерів; реалізація інтегративного методологічного підходу у педагогічному процесі, практико-орієнтований характер інженерної підготовки студентів; інтеграція навчальної, дослідницької $i$ виробничої діяльності майбутніх інженерів-аграрників; узгодження змісту агроінженерної освіти з перспективами кадрових потреб аграрного виробництва.

Ключові слова: інженерна діяльність, фрункції, компетентнісний підхід, інженер-аграрник, аграрний вищий навчальний заклад, сільськогосподарські машини.

Вступ. Сьогодні поширюється попит на інженерів, які здатні не тільки успішно працювати в певних технічних галузях науки, а й володіти компетентностями в галузях управління якістю, надійністю продукції, екологічного права, маркетингу, управління персоналом тощо. Головною метою майбутніх інженерів $€$ фрормування їх методологічної культури - сукупності умінь «бачити» інженернотехнічні проблеми, формулювати і творчо розв'язувати професійні завдання, проектувати і конструювати власну діяльність з високим рівнем рефрлексії. 
Натомість узвичаєний педагогічний процес аграрних вишів поки що недостатньо мобільно переорієнтовується 3 логіки традиційної освіти (спочатку знання про всяк випадок, а потім організація дій щодо їх застосування) на логіку компетентнісної освіти. У зв'язку з цим модернізація профресійної підготовки інженерів-аграрників на засадах компетентнісної концепції $€$ однією 3 найбільш важливих проблем вищої аграрної освіти.

Концептуальні засади підготовки сучасних інженерних кадрів обґрунтовано в працях І. Бендери, О. Дьоміна, В. Журавського,оО. Коваленко, М. Лазарєва, П. Лузана, В. Манька, С. Моторної, В. Шило, Ю. Нагірного, В. Олексенко, О. Романовського, А. Слободянюка, І. Хом'юк, П. Стефраненко, А. Чучаліна, П. Яковишина та ін. Теорія компетентнісно-орієнтованого підходу до навчання викладена у працях С. Амеліної, Н. Бібік, В. Безпалька, Е. Зеєра, І. Зимньої, І. Зязюна, Н. Кузьміної, А. Маркової, Л. Мітіної, О. Овчарук, В. Лугового, Л. Пуховської, М. Розова, О. Савченко, Г. Терещука, А. Хуторського, В. Шапкіна.

Однак, не заперечуючи безумовну важливість досліджень сучасних учених, проблема формування професійної компетентності майбутніх інженерів з механізації сільського господарства в аграрному вищому навчальному закладі залишається недостатньо вивченою і потребує систематизації, теоретичного узагальнення, використання нових наукових та емпіричних досліджень та підходів до її розв'язання.

Мета статті - за результатами аналізу особливостей сучасної інженерної діяльності, стану професійної підготовки інженерів-механіків сільського господарства, наявних досліджень учених виділити перспективні напрями модернізації процесу формування професійної компетентності вказаних фрахівців.

Виклад основного матеріалу. Інженерна діяльність сьогодення 
все більше набуває комплексного, інноваційного характеру; інженер, в арсеналі якого ґрунтовна методологічна підготовка, необмежені інформаційні ресурси і потужні комп'ютерні системи, може комплексно розв'язувати дослідницькі, проектні, конструкторські, технологічні та інші завдання; комплексна інженерна діяльність є багатокомпонентною і охоплює широкий спектр інженерно-технічних проблем. Головним вектором розвитку технологічних процесів у нинішньому постіндустріальному суспільстві $€$ автоматизація, поступова заміна некваліфікованої праці роботою машин, комп'ютерів. Тому є доцільним детальніше розглянути види і функції діяльності сучасного інженера, зокрема в галузі механізації сільського господарства. Принагідно додамо, що основні функції інженера достатньо жорстко розподілено і закріплено за певними спеціальностями [2; 5; 6].

1. Функція аналізу i технічного прогнозування. Виконання цієї функції інженером пов'язане з встановленням технічних суперечностей і потреб виробництва продукції. Насамперед, виконання цієї інженерної функції забезпечує прогнозування технічного розвитку галузі, визначення технічних перспектив. Здійснюють таку прогностичну діяльність досвідчені інженери - керівники, провідні спеціалісти проектно-конструкторських і науково-дослідних інститутів, головні інженери, технологи заводів, фрабрик, конструкторських бюро, лабораторій тощо.

2. Дослідницька фуннція інженерної діяльності передбачає регулярне застосування наукових знань для пошуку принципової схеми технічного обладнання чи технологічного процесу, створення штучних, технічних систем. Виконання означених завдань вимагає від інженера застосовування системного підходу до розв'язання складних науковотехнічних завдань, використання знань з соціальних, гуманітарних, природничих, технічних дисциплін. Тому з одного боку інженер 
орієнтується на науку, що вивчає природу, а з іншого - на виробництво, що включає певний практичний досвід.

3. Конструкторська функція інженера доповнює і розвиває дослідницьку, а інколи і поєднується з нею. Особливості її змісту полягають у тому, що від інженера-дослідника конструктор бере ідею, принцип, «голий скелет принципової схеми» приладу, механізму, розробляє кресленики, виготовляє, випробовує дослідні зразки різних варіантів майбутнього інженерного об'єкта, узгоджує результати із замовником, створює технічний, а потім і робочий проект - технічну документацію для виробництва.

4. Функція проектування є найбільш суміжною до дослідницької і конструкторської функцій інженерної діяльності. Зазвичай, розрізняють «внутрішнє» і «зовнішнє» проектування. У першому випадку маємо справу з розробкою робочих креслеників (ескізного, технічного і робочого проектів), що є основними документами для виготовлення технічної системи на виробництві. «Зовнішнє» проектування спрямовано на опрацювання спільної ідеї системи, її дослідження за допомогою теоретичних засобів технічних наук. Вихідним для проектувальної інженерної діяльності $\epsilon$ соціальне замовлення, а продуктом - тексти, кресленики, розрахунки, комп'ютерні моделі тощо. Цим проектування суттєво відрізняється від конструювання, за якого результат має бути матеріалізований у вигляді дослідного зразка, за допомогою якого уточнюються проектні розрахунки.

5. Технологічна фуннція інженерної діяльності пов'язана 3 відповіддю на запитання: як виготовити те, що винайдено? Інженертехнолог має поєднати технічні процеси з трудовими, досягти того, щоб в результаті взаємодії працівників і техніки економічні затрати були мінімальними, а технічна система працювала продуктивно. Варто погодитися з тим, що успішного інженера-технолога характеризують 
такі провідні здатності [2; 5]: уміння здійснювати підготовку виробництва продукції; впровадження у виробництво нових технологічних процесів; реалізацію технологічних рішень; забезпечувати оптимальний режим роботи обладнання та ін.

6. Функція регулювання виробництва. Інженер-проектувальник, інженер-конструктор та інженер технолог засобами спільної діяльності визначили, який технічний об'єкт виготовляти і як виготовляти. Безпосередню організацію виробництва продукції здійснюють інженери-виробничники (наприклад, завідувач майстернею з ремонту тракторів і сільськогосподарських машин, завідувач машинним двором, завідувач автогаражем тощо). Інженери-виконавці робіт на місцях підпорядковують спільну діяльність працівників виконанню конкретного технічного завдання. Складовими їхньої професійної компетентності $\epsilon$ : уміння контролювати та стимулювати процес реалізації операторами прийнятих рішень; уміння стимулювати розвиток професійної компетентності працівників; уміння стимулювати процес оптимізації прийняття рішень операторами; уміння здійснювати контроль параметрів виробів, роботи машин та їх механізмів.

7. Функція експлуатації і ремонту обладнання. Складна сучасна техніка, у тому числі і сільськогосподарська, вимагає інженерної підготовки від працівників, котрі її обслуговують. В обов'язки інженерівексплуатаційників входить налагодження й технічне обслуговування машин, автоматів, технологічних ліній, контроль за режимом їх роботи. Все частіше саме ці інженери виконують роботу операторів. В умовах аграрного підприємства, це, наприклад, інженер з експлуатації машино-тракторного парку, інженер з механізації трудомістких процесів у тваринництві, інженер з технічного обслуговування машин тощо. 
Вищезазначені функції інженера найчастіше згадуються у працях, присвячених методології інженерно-технічної діяльності. Натомість зазначимо, що останнім часом все частіше дослідники говорять про системне проектування як новітню функцію інженера.

Щоб визначитися 3 напрямами модернізації узвичаєної професійної підготовки інженерів з механізації сільського господарства схарактеризуємо особливості і специфіку їх професійної діяльності в умовах сучасного аграрного виробництва:

1. Аграрне виробництво вимагає створення машин і знарядь, які за своєю будовою, характером і принципом роботи суттєво відрізняються від будівельної, транспортної техніки тощо. Сільськогосподарська техніка впливає не на безпосередні предмети праці, а на проміжне середовище - природу (грунт, рослина, тварина), яка й забезпечує одержання необхідної продукції. Цей фракт і спричинює специфічні агротехнічні, зооветеринарні вимоги до роботи техніки у сільськогосподарському виробництві.

2. Різноманітність об'єктів діяльності інженера-механіка сільського господарства - це система спеціальних технологічних приміщень для технічного обслуговування, налагодження і зберігання (рослинництво); технології, спеціальне обладнання, постачання води, енергії, тепла (переробка). 3 цього приводу В. Манько слушно вказує, що інженер 3 механізації сільського господарства виконує свої обов'язки на підприємствах безпосередньо сільськогосподарського виробництва (агрофрірми, кооперативні, акціонерні, орендні, фрермерські та інші господарства), або в службах його обслуговування (ремонтно-технічні, нафртогосподарства, автотранспортні тощо) [6].

3. Значна кількість польових, садових, овочевих та інших культур, поголів'я тварин, різні кліматичні та ґрунтові умови, різниця у рельєфі потребують надзвичайно розгалуженого комплексу машин, зокрема 
спеціальних. Оскільки сезонність зумовлює скорочення термінів їх використання, то машинний парк середнього за розмірами аграрного підприємства чи організації має розмаїття машин, їх типів, видів та марок. Неповторний характер сільськогосподарських операцій змушує створювати машини з вузькою спеціалізацією, що виключає можливість їх використання для інших технологічних процесів.

4. Важливою особливістю використання сільськогосподарської техніки є те, що машини мають пересуватися на великих площах. Технологічні операції виконують сільськогосподарські машинотракторні агрегати (MTA). Машинно-тракторний агрегат (MTA) - це сполучення мобільних машин із джерелом енергії, передавальними та іншими пристроями, призначеними для виконання однієї або декількох технологічних операцій [3]. Абсолютна більшість сільськогосподарських машин має агрегатуватися з мобільними енергетичними засобами тракторами, самохідними шасі тощо.

5. Специфічною відмінністю від промислового застосування техніки i, водночас, проблемою використання сільськогосподарської техніки є її вплив на навколишнє природне середовище. При недотриманні відповідних екологічних норм і принципів відбувається забруднення навколишнього середовища, наноситься шкода флорі і фауні (обприскування посівів пестицидами без попередження пасічників може призвести до отруєння бджіл; неправильна послідовність збирання зернових неодмінно призведе до загибелі диких тварин тощо).

6. Типове поєднання в одному господарстві таких галузей, як: рослинництво, тваринництво, переробка продукції спричинює специфічну лише для аграрних підприємств і організацій структуру інженерно-технічної служби. Відповідно, специфічними $є$ функції 
діяльності інженерів з механізації сільськогосподарського виробництва, які корелюють з такими сферами діяльності цих фрахівців [6, с. 107]:

- організаційно-виробнича, суть якої полягає в забезпеченні ефективного функціювання і розвитку виробничих підприємств, охорони праці;

- виробничо-технологічна, спрямована на забезпечення ефективного фрункціювання і розвиток технологічних систем у сфері механізованого виробництва сільськогосподарської продукції, ії зберігання та переробку;

- сорера технічного сервісу забезпечує роботоздатність технічних засобів, їх ремонт, а також матеріально-технічне постачання;

- проектування і науково-інфрормаційне обслуговування виробництва, забезпечує розробку і удосконалення технологічних систем, формування і реалізацію науково-технічної політики, поширення прогресивних нововведень.

7. Особливості інженерної діяльності фрахівців-аграрників пов'язані також і з їхньою роботою в якості фермерів. На особливості роботи фермера вказує Т. Іщенко у монографії «Фахове навчання в системі безперервної аграрної освіти» [4, с. 186]: «Специфіка роботи фрермера повністю побудована на самостійній діяльності, в якій немає місця для часу на адаптацію до виробничих умов. У роботі за іншими спеціальностями помилки чи інші недоречності випускників у період адаптації (I не тільки в адаптаційний період. Зауваження наше. - К.О.) значною мірою упереджуються порадами досвідчених фрахівців, які працюють поблизу, і з якими можна вчасно порадитися, а у разі необхідності - одержати допомогу». Відмітимо, що вказана особливість певним чином відрізняє роботу й інженера пересічного агропромислового підприємства від роботи інженера-конструктора КБ, інженера науково-дослідної лабораторії НДІ, інженерно-технічних 
працівників заводу, автотранспортного підприємства тощо: часто інженеру-аграрнику доводиться розв'язувати повсякденні технічні проблеми з надією лише на власний обсяг знань і умінь.

8. Суттєвою відмінністю інженерної діяльності в агропромисловому виробництві $\epsilon$ фракт насичення машино-паркового господарства сільськогосподарських підприємств зарубіжною технікою. Це пов'язано з тим, що вітчизняне машинобудування поки що не здатне задовольнити потреби вітчизняного агропромислового комплексу у сільськогосподарській техніці. Наприклад, за підрахунками Національного наукового центру «Інституту аграрної економіки», основними сільськогосподарськими машинами аграрні підприємства всіх категорій забезпечені ледве на $50 \%$ [7, с. 24]. Повсякчас сільгоспвиробникам ринкові структури пропонують зарубіжні зразки комбайнів, тракторів, сівалок, машин поверхневого обробітку грунту.

Висновок. Враховуючи особливості інженерної діяльності, стан профресійної підготовки інженерів з механізації сільського господарства в аграрних вищих навчальних закладах, підходи учених до вказаної проблеми виокремлюємо такі перспективні напрями модернізації процесу фрормування професійної компетентності вказаних фрахівців: творчий характер навчання, фрормування готовності студентів до інноваційної інженерної діяльності; цілеспрямоване фрормування методологічної культури майбутніх інженерів; реалізація інтегративного методологічного підходу у педагогічному процесі, що відображає поліфункціональну інноваційну діяльність майбутнього фрахівця; практико-орієнтований характер інженерної підготовки студентів; інтеграція навчальної, дослідницької і виробничої діяльності майбутніх інженерів-аграрників; узгодження змісту агроінженерної освіти 3 перспективами кадрових потреб аграрного виробництва. 
Змістово-процесуальні аспекти фрормування професійної компетентності майбутніх інженерів-аграрників будуть обґрунтовані у подальших матеріалах дослідження.

\section{תimepamypa:}

1. Бендера I. М. Організація самостійної роботи студентів агроінженерних спеціальностей: Монографрія / І. М. Бендера. - К.: Наукметодцентр аграрної освіти, 2007. - 364 с.

2. Діденко М. К. Експлуатація МТП: підручник / М. К. Діденко. - К.: Вища школа, 1983. - 447 с.

3. Іщенко Т. Д. Фахове навчання в системі безперервної аграрної освіти: монографрія / Т. Д. Іщенко. - К.: Аграрна освіта, 2000. - 242 с. 4. Мануйлов В. Ф. Инновации в подготовке специалистов в области техники и технологии / В. Ф. Мануйлов, В. М. Приходько, В. М. Жураковский, И. В. Федоров // Инновационный университет и инновационное образование: модели, опыт, перспективы. - Томск: Изд-во ТПУ, 2003. - С. 14-16.

5. Манько В. М. Ступенева підготовка інженерів-механіків сільськогосподарського виробництва: монографрія / В. М. Манько, В.В. Іщенко. - К.: Науково-методичний центр аграрної освіти, 2005. - 506 C.

6. Петренко І. Як подолати дефіцит комбайнів/ I. Петренко // Агробізнес сьогодні. - № 11 (234). - червень 2012 р. - С. 24-25.

\section{References:}

1. Bendera I. M. Orghanizacija samostijnoji roboty studentiv aghroinzhenernykh specialjnostej: Monoghrafija / I. M. Bendera. - K.: Naukmetodcentr aghrarnoji osvity, 2007. - 364 s.

2. Didenko M. K. Ekspluatacija MTP: pidruchnyk / M. K. Didenko. - K.: Vyshha shkola, 1983. - 447 s. 
3. Ishhenko T. D. Fakhove navchannja $v$ systemi bezperervnoji aghrarnoji osvity: monoghrafija / T. D. Ishhenko. - K.: Aghrarna osvita, 2000. - 242 s.

4. Manuylov V. F. Innovatsii $v$ podgotovke spetsialistov $v$ oblasti tekhniki i tekhnologii / V. F. Manuylov, V. M. Prikhodko, V. M. Zhurakovskiy, I. V. Fedorov // Innovatsionnyy universitet $i$ innovatsionnoe obrazovanie: modeli, opyt, perspektivy. - Tomsk: Izd-vo TPU, 2003. - S. 14-16.

5. Manjko V. M. Stupeneva pidghotovka inzheneriv-mekhanikiv siljsjkoghospodarsjkogho vyrobnyctva: monoghrafija / V. M. Manjko, V. V. Ishhenko. - K.: Naukovo-metodychnyj centr aghrarnoji osvity, 2005. - 506 $S$.

6. Petrenko I. Jak podolaty deficyt kombajniv/ I. Petrenko // Aghrobiznes sjoghodni. - № 11 (234). - chervenj 2012 r. - S. 24-25. 